\title{
Architecture Modeling and Simulation for Supporting Multimedia Services in Broadband Wireless Networks"
}

\author{
Do-Hyeon $\mathrm{Kim}^{1}$ and Beongku $\mathrm{An}^{2}$ \\ ${ }^{1}$ School of Computer \& Telecommunication Engineering, \\ Cheju National University, Cjeju, South Korea \\ kimdh@cheju.ac.kr \\ ${ }^{2}$ Department of Electronic, Electrical \& Computer Engineering, \\ Hongik University, Jochiwon, South Korea \\ beongku@wow. hongik.ac.kr
}

\begin{abstract}
In this paper, we propose and evaluate two reference models for supporting wireless video broadcasting services based on ATM over LMDS in metropolitan area wireless access networks. Our proposed reference models, namely end-to-end ATM model and headend/server-to-hub ATM model, are characterized. The end-to-end ATM model supports transfer of the ATM cell between headend and set-top box located in the end of networks for the wireless video services. The headend/server-to-hub ATM model transfers the ATM cell between headend/server and hub, and transmits the LMDS frame in the MPEGTS over LMDS wireless access network. The performance evaluation of the proposed models is performed via analysis and simulation. The results evaluate delay and jitter of two proposed models. Especially, headend/server-to-hub ATM model has better performance than end-to-end ATM model for wireless video services because the end-to-end ATM model additionally needs more delay and jitter than headend/server-to-hub ATM model to convert the ATM cell to the LMDS frame.
\end{abstract}

\section{Introduction}

Recently, Broadband wireless access loop technologies are represented by MMDS (Multichannel Multipoint Distribution Service) and LMDS (Local Multipoint Distribution Service). Wireless video services use the wireless access loop such as LMDS instead of the coax cable for CATV and VoD (Video on Demand) service. Especially, we need the analysis about sensitive feature about the jitter and delay caused by the transmission of the video and image data in the broadband wireless multimedia networks $[3,4]$. However, in our study until now there are no reference models for supporting video services in broadband wireless networks.

This paper presents two reference models of the wireless video broadcasting services based on ATM over LMDS in metropolitan area wireless access networks. The first reference model is the end-to-end ATM model, where ATM cell is transferred between the set-top box and the headend/server. The second reference model is the headend/server-to-hub ATM model. In the second model, ATM cell is transmitted be-

* This work was supported by the Korea Research Foundation Grant.(KRF-2004-002-D00376). 
tween the hub and the headend/server in fixed network segment based on ATM, and MPEG2-TS (Transport Stream) is transferred to the set-top box in the radio access network segment using LMDS. We evaluate the performance of the proposed models in terms of the end-to-end delay and jitter of MPEG2-TS. In conclusion, the headend/server-to-hub ATM model can reduce more the delay and the jitter than endto-end ATM model.

\section{The Proposed Architecture Models}

Wireless access loop has more merits than the wired cable in the view points of the economical efficiency and network flexibility. Wireless video system based on LMDS/ATM consists of service provider, headend, hub, set-top box, etc. We propose two architecture models namely, the end-to-end ATM model and the headend/severto-hub ATM model, to support the wireless video services based on LMDS/ATM $[5,6]$.

The end-to-end ATM model supports transfer of the ATM cell between headend and set-top box located in the end of the wireless CATV or VoD system. This model uses the ATM backbone network and the LMDS wireless access network. In this model, the ATM cell is translated into LMDS frame to transmit the data between hub and set-top box, and LMDS frame is conversed into the ATM cell in set-top box. Figure 1 shows the protocol stack in end-to-end ATM model which supports the ATM protocol stack in all devices such as a headend, set-top box, hub, etc.

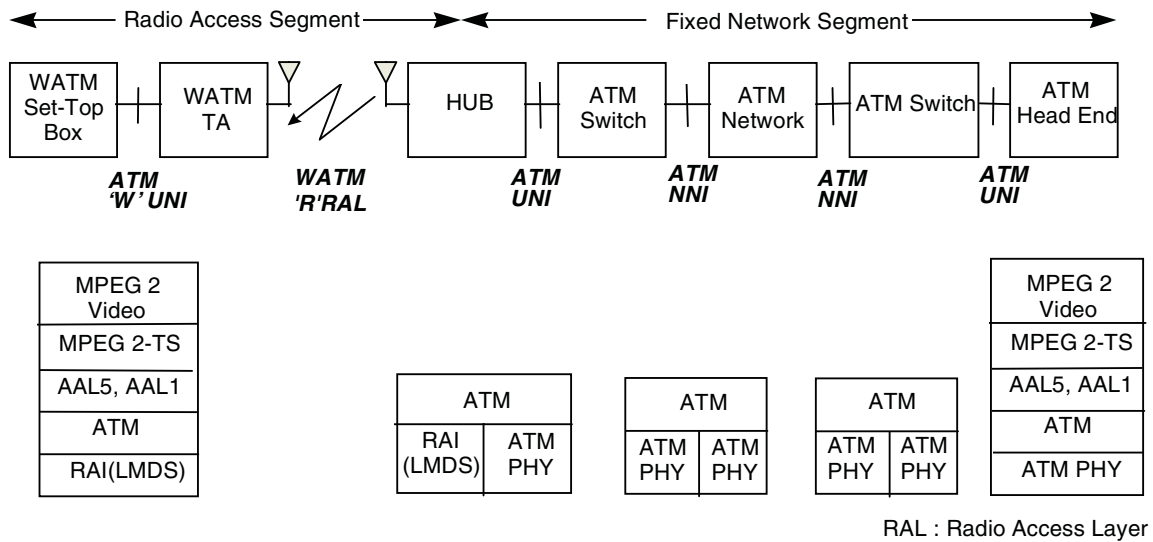

Fig. 1. End-to-end ATM model: Configuration and protocol stack

In the headend/server-to-hub ATM model, the ATM cell is transferred between headend/server and hub, and the LMDS frame included the MPEG-TS is transmitted in wireless access network. Then, the MPEG-TS frame is translated into LMDS frame to transmit the data between hub and set-top box. Especially, the main features of this proposed model is that the ATM cell is translated into MPEG2-TS frame and LMDS frame in hub, and conversed LMDS frame into the MPEG2-TS frame in set-top box. 
Figure 2 describes that the protocol in headend/server-to-hub ATM model can support the ATM protocol stack in all devices such as a headend and hub. The hub removes the AAL head of the ATM cell and recombines with the MPEG2-TS stream.

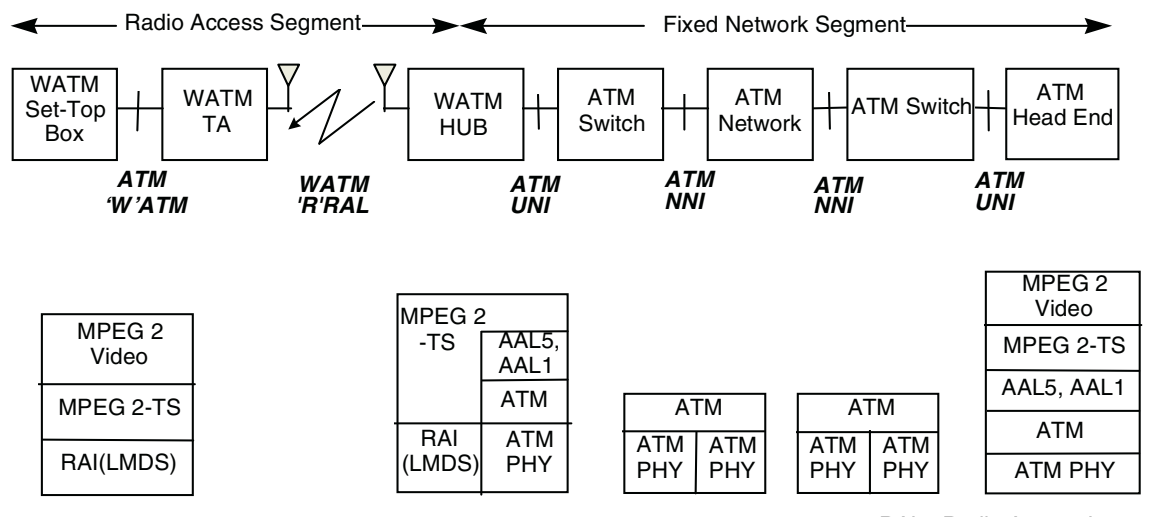

RAL : Radio Access Layer

Fig. 2. Headend/server-to-hub ATM model: Configuration and protocol stack

\section{Performance Evaluations}

To verify the performance, we analyze jitter factors that happen in headend/server, hub and set-top box in the headend/server-to-hub model and end-to-end ATM model. We quantatively analyze the models in terms of end-to-end delay and jitter of MPEG2-TS and perform simulation using OPNET (Optimized Network Engineering Tool) by MIL3 company .

Table 1. End-to-end delay of MPEG2-TS in the end-to-end ATM model

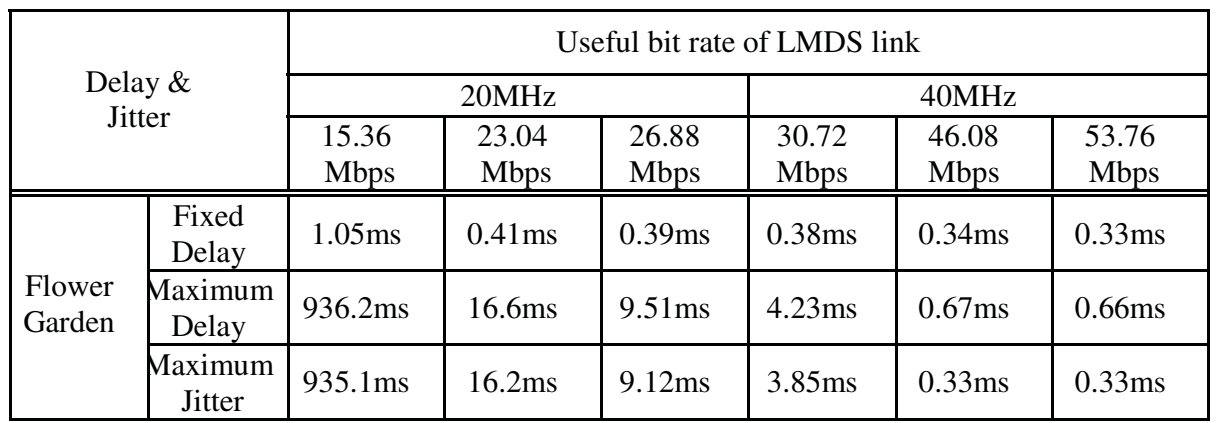

The simulation environment of wireless video service networks based on LMDS/ATM consists of the video source, server/headend, hub and set-top box. We assume that the distance from headend to hub sets by $50 \mathrm{Km}$ which is the size of a traditional CATV service area, and radio LMDS transmission link between the hub and 
set-top box establishes by $5 \mathrm{Km}$. The transfer speed of the $155 \mathrm{Mbps}$ recommended by the ATM forum between server and hub is used, while the flower garden image is used.

The fixed end-to-end delay is $0.39 \mathrm{~ms}$ and the jitter is between $0.39 \mathrm{~ms}$ and $0.68 \mathrm{~ms}$ at the radio channel speed $26.88 \mathrm{Mbps}$ used flower garden images in the end-to-end ATM model. Especially, jitter has a high probability value between $0.44 \mathrm{~ms}$ and $0.57 \mathrm{~ms}$ because the conversion of MPEG2-TS to AAL5 PDU and ATM cell to LMDS frame cause much jitter factor. In the table 1, we present the maximum end-to-end delay and jitter of MPEG2-TS for football and flower garden images according to radio channel speed.

Table 2. End-to-end delay of MPEG2-TS in the headend/server-to-hub ATM model

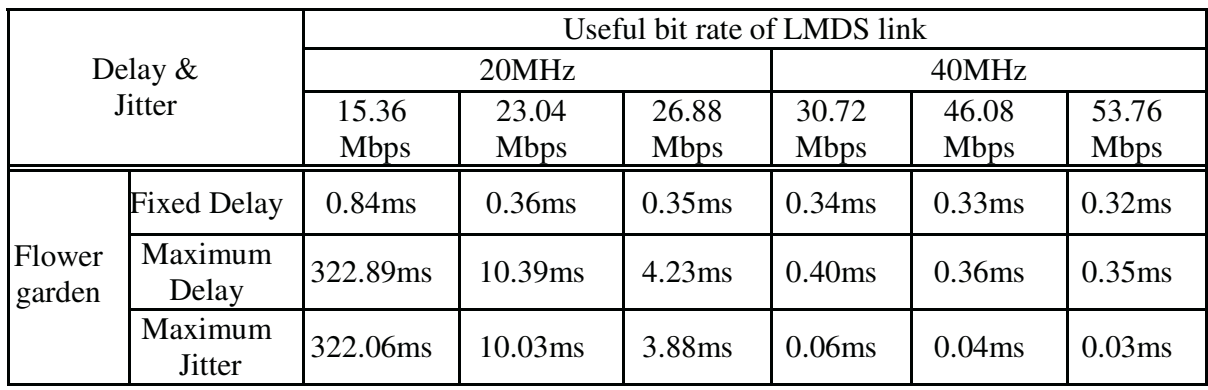

The fixed end-to-end delay is $0.35 \mathrm{~ms}$ and the jitter is between $0.35 \mathrm{~ms}$ and $0.42 \mathrm{~ms}$ at the radio channel speed $26.88 \mathrm{Mbps}$ used flower garden images in the headend/server-to-hub ATM model. In the table 2, we present the maximum end-toend delay and jitter of MPEG2-TS for football and flower garden images according to radio channel speed. The simulation results demonstrate the delay and jitter of two proposed models in the wireless CATV and wireless VoD service based on LMDS/ATM. Especially, headend/server-to-hub ATM model has better performance than end-to-end ATM model for wireless video services because additionally the endto-end ATM model needs more delay and jitter than headend/server-to-hub ATM model to convert the ATM cell to the LMDS frame.

\section{References}

1. Digital Audio Video Council Technical Report, DAVIC 1.1 Specification Part 08.

2. ATM Forum Technical Committee, Audiovisual Multimedia Services : Video on Demand Specification 1.0.

3. Dipankar Raychaudhuri, "ATM-based Transport Architecture for Multi-services Wireless Personal Communication Networks," IEEE JSAC, Vol.12, No.8, pp. 1401 1414, Oct. 1994.

4. Bruno Cornaglia, Riccardo Santaniello and Enrico Scarrone, "Proposal for the protocol reference model for WATM," ATM Forum/96-1650, Dec. 1996.

5. Melbourne Barton, Daniel Pinto, et al., "Reference configuration model for wireless ATM," ATM Forum/96-1623, Dec. 1996.

6. "ISO/IEC 13818-6: MPEG-2 Digital Storage Media Command and Control," ISO/IEC JTC1/SC29/WG11, Mar. 1995. 